\title{
Otulipenia, Penyakit Inflamasi Baru yang Mematikan dan Menyerang Anak-Anak
}

\author{
Hafshah Nurul Afifah \\ PT. Cendo Pharmaceutical Industries, Bandung, J awa Barat, Indonesia \\ Terbit online : 5 September 2016
}

\section{Abstrak :}

Sekelompok peneliti menemukan suatu kondisi inflamasi baru yang disebut otulipenia yang umumnya menyerang anak-anak dibawah 12 tahun. Penyakit langka dan sering kali mematikan ini menyebabkan kegagalan fungsi otulin, suatu gen tunggal pada kromosom 5 . Kelompok peneliti ini menemukan keabnormalan gen otulin pada 4 anak dari keluarga Pakistan dan Turki yang mengalami ruam kulit dan peradangan sendi yang tidak dapat dijelaskan. Selain menemukan kategori baru penyakit inflamasi pada manusia yang disebabkan oleh kegagalan ubiquitinasi, peneliti juga merekomendasikan hasil penelitian yang dapat mendorong pengembangan terapi baru untuk pasien penderita penyakitinflamasi dalam rentang yang luas.

Keyword : otulipenia, inflamasi

\section{Pendahuluan}

Sekelompok peneliti menemukan suatu kondisi inflamasi baru yang disebut otulipenia yang umumnya menyerang anak-anak dibawah 12 tahun. Penyakit langka dan sering kali mematikan ini menyebabkan kegagalan fungsi otulin, suatu gen tunggal pada kromosom 5 . Jika otulin berfungsi dengan semestinya, tubuh dapat membentuk pembuluh darah yang mampu melawan infeksi secara efektif dengan memobilisasi berbagai sel dan protein.

\section{Apa itu inflamasi?}

Meskipun kita terbiasa mengaitkan inflamasi atau radang dengan rasa nyeri dan tidak nyaman serta banyak penyakit kronis, proses ini sebenarnya bukan sesuatu yang buruk. Ketika bakteri atau virus masuk ke dalam tubuh, suatu respon biologis yang kompleks yang melibatkan deretan senyawa biokimia mulai terjadi. Proses yang sepenuhnya normal ini, yang melibatkan berbagai jenis sel imun, protein pembekuan, dan molekul sinyal, dinamakan inflamasi akut. Inflamasi ini adalah respon protektif tubuh terhadap luka atau infeksi yang menyebabkan pelebaran pembuluh darah, menghasilkan peningkatan aliran cairan dan sel-sel imun yang mengelilingi jaringan.

Sayangnya, inflamasi kronis terkadang terjadi dan berlangsung terus-menenus tanpa penyembuhan. Pada kasus ini, sistem imun tubuh keliru memulai respon inflamasi, meskipun tidak ada luka yang tampak atau infeksi yang perlu dilawan.

\section{Peneliti temukan penyakit inflamasi baru}

Kelompok peneliti dari US National Institutes of Health menemukan suatu kondisi inflamasi baru yang disebut otulipenia yang umumnya menyeranganak-anak dibawah 12 tahun. Penyakit langka dan sering kali mematikan ini menyebabkan kegagalan fungsi otulin, suatu gen tunggal pada kromosom 5. Jika otulin berfungsi dengan semestinya, tubuh dapat membentuk pembuluh darah dan melawan infeksi secara efektif dengan memobilisasi berbagai sel dan protein. 
Kelompok peneliti ini menemukan keabnormalan gen otulin pada 4 anak dari keluarga Pakistan dan Turki yang mengalami ruam kulit dan peradangan sendi yang tidak dapat dijelaskan. Pada studi lebih lanjut, para penelit ini menemukan masalah pada mekanisme ubiquitin (suatu protein berukuran kecil yang penting dalam regulasi berbagai protein dalam tubuh, temasuk molekulmolekul imun) dihilangkan dari tubuh. Ketidakmampuan untuk menghilangkan protein ubiquitin dari berbagai molekul dapat menyebabkan peningkatan produksi sitokin inflamasi, senyawa kimia pembawa pesan yang menyebabkan inflamasi.

Para peneliti kemudian segera menemukan bahwa anak-anak penderita penyakit inflamasi ini yang diobati dengan inhibitor tumor necrosis factor (TNF) merespon dengan baik dan mengalami pemulihan inflamasi, kemungkinan besar karena TNF merupakan senyawa kimia pembawa pesan yang terlibat dalam inflamasi sistemik.

Inhibitor TNF digunakan untuk mengobati penyakit inflamasi kronis lainnya, seperti artrits reumatoid, artritis psoriatik, dan artritis juvenile. Obat-obat golongan ini meliputi infliximab, etanercept, adalimumab, certolizumab pegol, dan golimumab.

Selain menemukan kategor baru penyakit inflamasi pada manusia yang disebabkan oleh kegagalan ubiquitinasi, penelit juga merekomendasikan hasil penelitian yang dapat mendorong pengembangan terapi baru untuk pasien penderita penyakit inflamasidalam rentang yangluas.

Daftar pustaka :

http://www.pharmacytimes.com/contributor/beth-bolt-rph/2016/09/researchers-discover-newinflammatory-disease-affecting-young-children. Diakses 5 September 2016.

Qing Zhou et. al. Biallelic hypomorphic mutations in a linear deubiquitinase define otulipenia, an early-onset autoinflammatory disease. PNAS. vol. 113 no. 36, (10127-10132) 2016. 